\title{
The Use of Web-Based Dynamic Maps in the Promotion of the Titel Loess Plateau (Vojvodina, Serbia), a Potential Geotourism Destination
}

\author{
Đorđije Vasiljevićc ${ }^{1 *}$, Slobodan B. Marković', Thomas A. Hose', Biljana Basarin', \\ Lazar Lazić', Vladimir Stojanović', Tin Lukić', Nada Vidić', \\ Goran Jović ${ }^{4}$, Sava Janićević', Darko Samardžija ${ }^{5}$ \\ Received: April 2009 | Revised: August 2009 | Accepted: August 2009
}

\begin{abstract}
Nowadays, the most common medium used to promote tourist destinations is the internet. Amongst the great advantages of the internet in the tourism business is that it enables the customer to have much easier and direct access to a very large amount of up-to-date information and visual description of desirable location than traditional printed media.

It is nothing new to claim that tourism and maps are inseparable. Some web sites from countries where tourism is a major source of income, or destinations that depend on internet marketing, still make little use of maps, or at the most very simple and static maps. Alternatively, there are interactive maps that come into common use in recent years. These maps provide interactivity with their users by giving them exactly the information that is desired, saving time and space.

Because of the unique and attractive landscape of the loess region of Vojvodina, there are some intentions by certain organisations to develop and promote this area as a geotourism destination. The purpose of this study is to present web-based dynamic maps from geographic sources promoted on the internet that could be later integrated into official websites.
\end{abstract}

Keywords: Titel loess plateau, geopark, geotourism, web-based dynamic maps, Vojvodina, Serbia

\section{Introduction}

In the last two decades, the concept of geoheritage has gained an increasingly important role in the field of fundamental researches, nature conservation, and also tourism. New trends in tourism have seen the evolution from mass tourism to sustainable tourism and the recognition of its associated activities, such as geotourism (Hose, 1995; Hose, 2005a). Geotourism itself can be considered as a form of niche tourism - the provision of which is focussed on relatively small, possibly elite, numbers of tourists with an interest in specific tourism places and products. Further it is predicated upon the development of increasingly experienced and sophisticated tourists demanding specialist holidays and services to meet their needs and desired experiences. Such tourists will also generate demand for specific products that enhance their holidays; these can range from the provision of dedicated clothing and equip-

1 Department of Geography, Tourism and Hotel Management, Faculty of Sciences, University of Novi Sad, Trg Dositeja Obradovića 3, 21000 Novi Sad, Serbia

2 School of Sport, Leisure and Travel, Faculty of Enterprise and Innovation, Buckinghamshire New University, Wellesbourne Campus, Kingshill Road, High Wycombe, Buckinghamshire, HP13 5BB, United Kingdom

3 Faculty of Sport and Tourism, Radnička 30a, 21000 Novi Sad, Serbia

${ }^{4}$ Department of Geography, Faculty of Sciences, University of Niš, Višegradska 33, 18000 Niš, Serbia.

5 Apatinska pivara A.D., a memeber of InBev, Apatinska 4, 21000 Novi Sad, Serbia

* Corresponding author: Djordije Vasiljević, e-mail: djordjijevasiljevic@yahoo.com 
ment to guide-books and maps. However, such tourists are also likely to consume the products and services associated with and originally developed for mass tourism such as transport and accommodation infrastructure. Geotourism, as niche tourism, is interpreted as mean by which tourists can appreciate geological and geomorphological processes and phenomena. Thereby, geotourism contributes to better interpretation and understanding of environment (Stojanović, Stamenković, 2008). Given the presence of unique and attractive geological regions in Serbia, there are some intentions by certain organisations (National Board for Geoheritage, Nature Protection Institute and Chair of Physical Geography of Department for Geography, Tourism and Hotel Management from Novi Sad) to develop and promote several geotourism destinations in this country.

Based on a comprehensive data set collected and collated in a proposal report to decree the Titel loess plateau as Geopark and detailed research of loess sediments in Vojvodina (Marković, et al. 2003, 2004a, 2004b, 2005a, 2005b, 2006a, 2006b, 2007a, 2007b, 2008, 2009; Fuchs, et al., 2008; Buggle, 2008, 2009; Antoine et al., 2009; Bokhorst, et al., 2009), it is possible to prepare a web-based tourist information system that would be of great purpose and utility for potential and present visitors to this future geotourism destination.
In this study we propose presenting web-based dynamic maps from the geographic and touristic information system of the potential Loess Geopark reported by Vasiljević (2008). The purpose of this paper is to present a case study of how tourism destinations (in this case a potential geotourism destination) can be marketed effectively on the Internet by employing interactive thematic maps used within this future tourism destination web site and other up-todate media.

\section{Titel loess plateau - \\ potential geotourism destination}

Recent years have shown that the idea of geological heritage gained more important role in the field of fundamental researches, nature conservation (Barretino, et al, 2000) and tourism (Hose, 2005a). The perfect example of this statement is a Geopark, the area with the highest level of geo-heritage conservation, especially unique geologic characteristic of its area. New trends in tourism have evolved from mass tourism to tourism that sustains or enhances the geographic character of the place being visited, including its environment, culture, aesthetics and heritage - geotourism (http://www.nationalgeographic.com/travel/sustainable/about_geotourism. html), although this USA National Geographic promoted

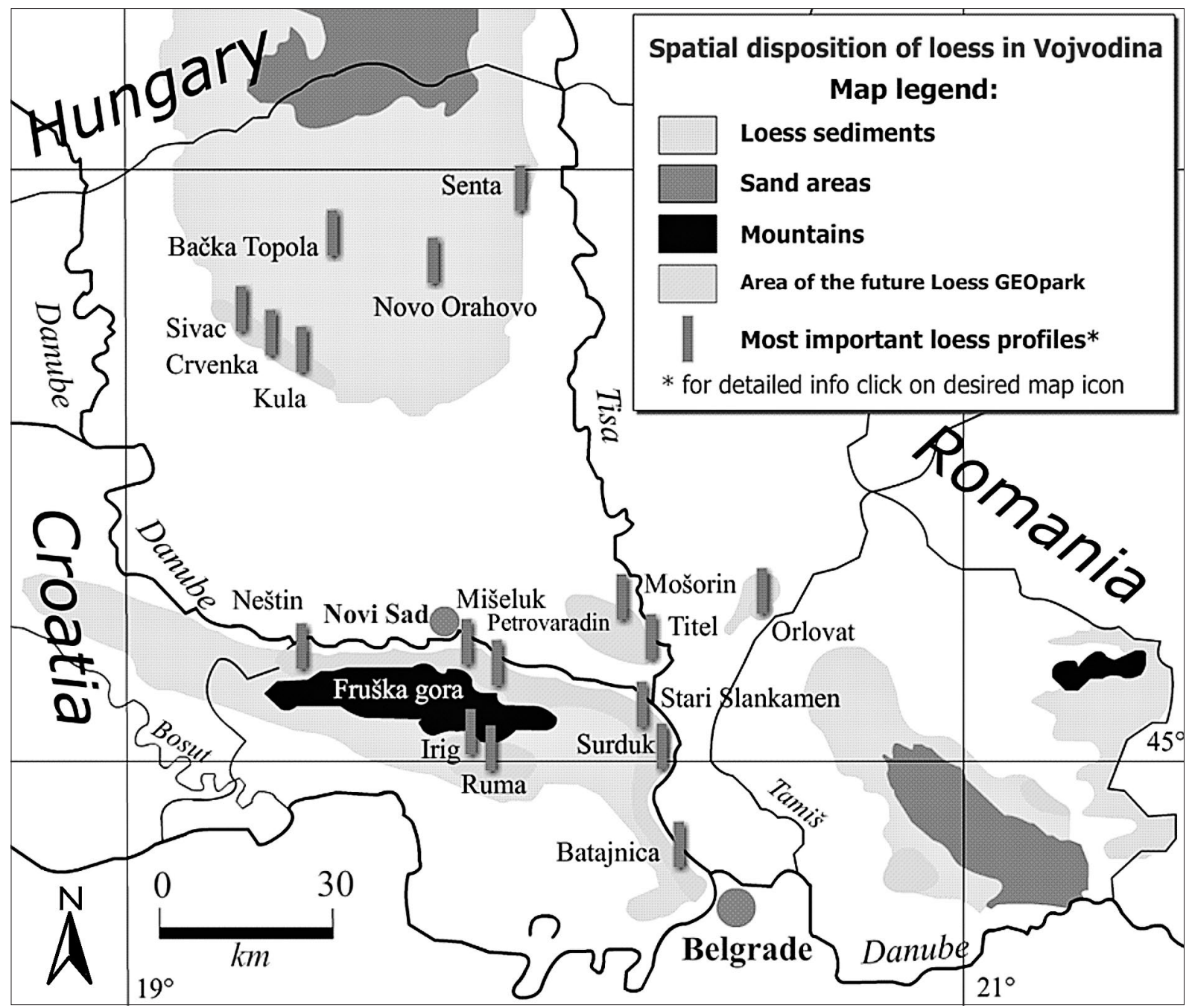

Figure 1 Spatial disposition of loess in Vojvodina (after Marković et al., 2004a; Vasiljević, 2008 modified) 
approach is a geographic rather than a purely geologic one (see Hose, 2008). Geotourism as initially defined (Hose, 1995) and redefined (Hose, 2003; Hose, 2008) is focussed on the promotion of geologic and geomorphic sites for their scientific and societal value to ensure their conservation for future use by academics, tourists and casual recreationalists. Geotourism research has also focussed on the development of communicatively competent tourism media (Hose, 2003; Hose, 2005b) although there is sometimes limited evidence within Europe that this has been applied (Hose, 1999) in either traditional or new media.

Taking into account the presence of the scientifically attractive and significant landscapes of the loess region of Vojvodina, the National Board for geological heritage, in collaboration with Nature Protection Institute and Chair of Physical Geography of Department for Geography, Tourism and Hotel Management from Novi Sad, has created the project of the Loess Geopark in Serbia. Since this protected area (due to dispersive spreading of loess sediments in Vojvodina) would have a dispersive characteristic (Figure 1), this paper includes only the Titel loess plateau as it is its largest enclave. The most detailed review of geoheritage of the Titel plateau is presented in paper Marković, et al., 2005a.

The Titel loess plateau (Vojvodina, Serbia) is situated in the confluence of the Danube and Tisa rivers, in the southeastern part of the Backka subregion. This unique geomorphologic phenomenon well represents the wide diversity of the loess landforms. The Titel plateau is in fact a loess island with a maximal extension of about $16 \mathrm{~km}$ and a maximum width of $7.2 \mathrm{~km}$. Thick loess deposits from 35 to $55 \mathrm{~m}$, separated by 5 main pedocomplexes deposited thought the last 5 glacial/interglacial cycles (Marković, et al., 2005a; Zeeden, et al., 2007), are represented within the stratigraphical sequence of the plateau. Steep loess cliffs include several important loess exposures essential to an understanding of climatic and environmental evolution during the middle and late Pleistocene in this region. (e.g. Pecsi, 1966; Butrym, et al., 1991; Bronger, 1976, 2003; Marković, et al., 2008; Gaudenyi, et al., 2007). The paleosol succession presents clear evidence of a paleoclimatic transition from humid middle Pleistocene to drier late Pleistocene climates (Bronger, 1976, 2003; Butrym, et al., 1991; Marković, et al., 2005a). This isolated loess island, with its morphology, dominates its lower surroundings which makes it aesthetically unique. F. ex. these facts prove that the Titel loess plateau represents a unique archive of paleoclimatic and paleoecologic changes that occurred in this area over the past 650,000 years. Furthermore, contemporary quaternary research conducted during recent years have confirmed the visionary work of the famous Hungarian geologist Jene Cholnoki, who, in the early years of the $20^{\text {th }}$ century, named this plateau Zeugeuberg - “witness hill” (e.g. Marković, et al., 2005a).

\section{Tourism marketing on the Internet and use of maps}

The Internet is an extremely powerful and relatively inexpensive - in comparison to traditional printed and direct mail material - tool that can be used to remain competitive and successful in the world of tourism marketing and it was anticipated that: "At the present rate of growth, every man, woman, and child on earth will have access to the Internet by the year 2000" (Mathiesen, 1995, p.3); however, this is still far from the case, although within Europe, despite marked variation between individual countries, progress has been made in its widespread availability and it has become a major medium for potential tourists to find out about and book trips to holiday destinations. Early in the development of the geotourism concept the use of multi-media and the Internet together for geotourism and ge oconservation were highlighted as a major way forward in promoting conserved landscapes; indeed the advent of high quality and relatively low cost digital imaging and printing technology: “. . . could be exploited to enable the rapid turnaround and updating of semi-permanent [tourist information] panels. [which] . . . should conform to . . . a coherent and recognisable 'house style' [that] could readily attain pan-European access on electronic templates ..." (Hose, 2000, p.145).

The evolution of the Internet, from a research tool into a free network that anyone may use, means that marketers are now free to adopt it as a low-cost high-reach marketing tool. Consequently, tourism destination marketers must ensure that it is appropriate to market their destination on the Internet, in order to reach the desired audience through their Web marketing efforts (Richmond, 2002). Marketing via web sites provides unlimited advertising space where text can be com bined with pictures, graphics, maps, animation, and even audio and video. The main idea here is to create a desirable image of the specific tourism destination in the mind of potential (future) visitors. One of the best ways to make this visual effect is by using maps. Maps are indispensable vehicles for communicating spatial information and creating images of space and place (Zonn, 1990) and that is why they play a significant role in how we discover, learn, and communicate information about the world around us.

There is great variety in the use of maps on tourist websites. Some web sites from countries, where tourism is a major source of income, or destinations that depend on internet marketing, still make little use of maps, or at the most very simple, static maps. Scanned paper maps, despite their disadvantages, are still widely used but it is only a matter of time before static, view-only maps will be succeeded by interactive ones and become rare in use. There are signs, how ever, that more tourist organisations are recognising the usefulness of maps on the World Wide Web (WWW) and particularly their interactive aspects. On a well-developed site, the user can, for example, plan a route, call up symbols on the map for places of interest and accommodation addresses, view related photographs, and go to related sites, book travel and accommodation (Kraak, et al., 2001).

It is nothing new to claim that tourism and maps are inseparable. From early adventurers who used rudimentary maps and charts to explore "new" worlds, to the modern-day tourist who uses a travel map to navigate within a chosen destination. Modern technology, which certainly includes computers and the Internet, is a very efficient vehicle used to present and disseminate geospatial data. Among the great advantages of the Internet in the tourism business is that it enables the customer to have much easier and 
direct access to a very large amount of up-to-date information and a visual description of desirable location. This results a creation of an interactive digital tourist map that allows the end user to take a "virtual tour" without leaving the travel agency, and at the same time having access to all available information on a particular point of interest and any additional related data (Kariotis et al., 2007).

Maps on the web have become common in a very short time. They can be either static or dynamic. Web images can be stored in raster or in vector based graphic format. Raster-based web maps are relative easy to generate by means of GIS software, by scanning existing paper maps or by drawing them in one the many graphic software packages such as Adobe Photoshop, PaintShop Pro, CorelPaint or Macromedia Fireworks.

Further technological developments have provided new tools and techniques for interface and interaction design of web map sites, such as Google Maps, MSN Maps \& Directions, MapQuest and Multimap.com (Nivala et al., 2007). These are web mapping services application and technology that power many map-based services and maps embedded on third-party websites.

There is a high demand for maps on the Internet. However, as previously stated, most of the presented maps are of low (carto) graphical quality and few of them are interactive. This fact is due to a lack of standardized technology and limited know-how in programming, graphics design and additional web-techniques. Despite their numerous advantages, vector based maps (such as those stored in Scalable Vector Graphics - SVG or Flash format) are rare on the web. The most obvious advantages are: unlimited zooming without loss of image quality, the possibility to include in the same file as well vector as raster based map objects and extreme small file-sizes compared to raster-based maps with a similar content. However, the biggest advantage is the extensive capacity to include interactivity and dynamics. With the rise of SVG there is for the first time a technology at hand that allows representing all graphical elements producible by graphics and cartographic-software with the additional advantages of high interaction possibilities and animation (Neuman, et al., 2001).

\section{Creating dynamic web maps of Titel loess plateau}

This study presents several proposed thematic interactive maps of the Titel loess plateau and its surrounding area, based on data obtained by the Nature Protection Organization of Serbia and representative papers from the Department for Geography, Tourism and Hotel Management from Novi Sad. Digitalisation and animation process was carried out with Macromedia Flash 8, often used to create two-dimensional animation, advertisements, and various web page components, to integrate video into web pages, and more recently, to develop rich internet applications. Detailed information on digitalisation and animation of these maps is presented in the Master's Thesis “Tourist and Geographic Information System of Future Loess Geopark in Serbia" by Vasiljević (2008).

The project aims to produce several maps with various themes, and different kinds of interactivity. The first example is a pedologic map (Figure 2), which is created from a map that was developed by the Nature Protection Organization of Serbia. This interactive map will provide its users with the disposition of all soil types in the area. Users will, by simple clicking on the desired soil type from the map legend (map menu) on the right, be able to turn on or off certain soils from the map. There is an unlimited amount

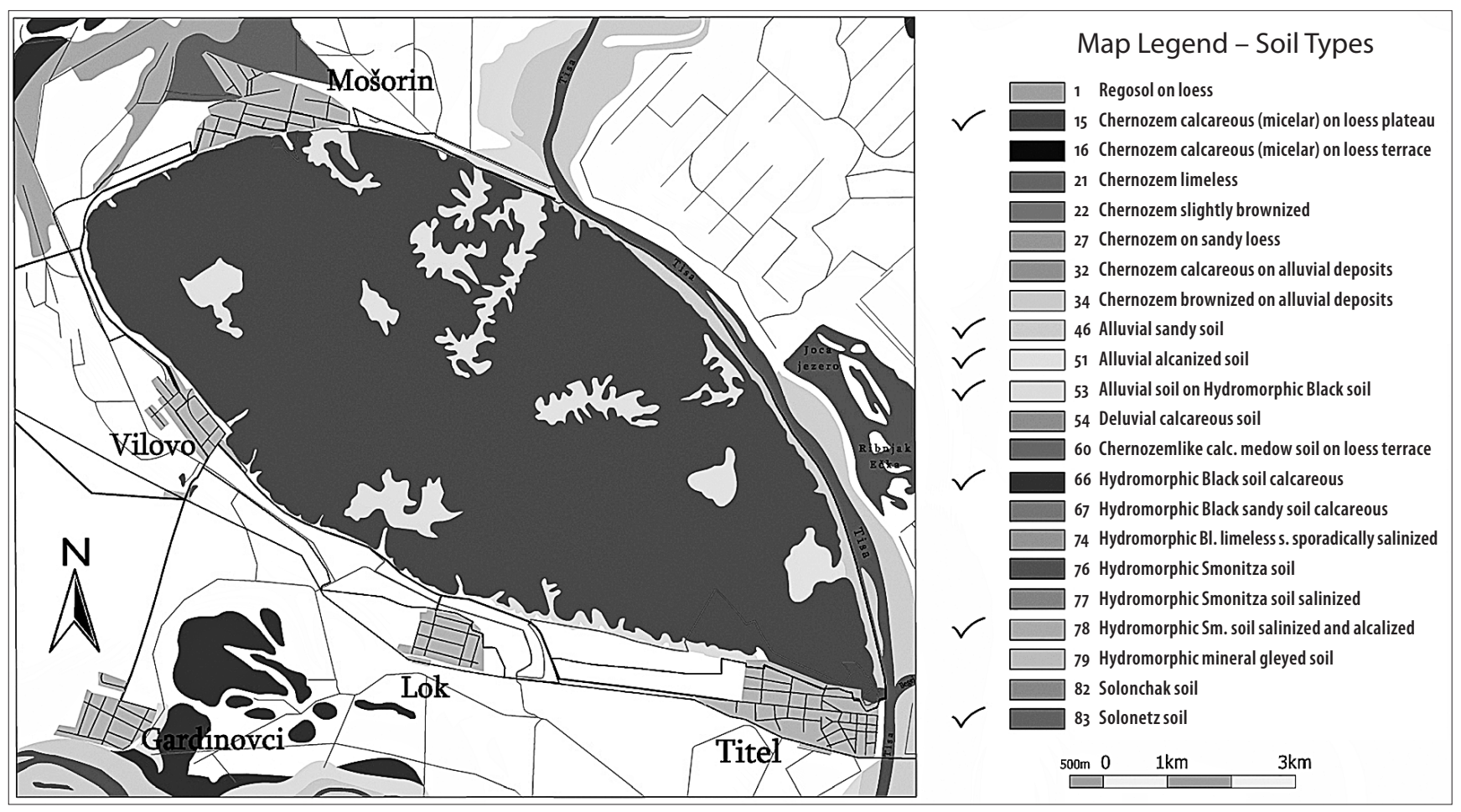

Figure $\mathbf{2}$ Pedologic map of Titel loess plateau with randomly presented soil types (Vasiljević, 2008) 


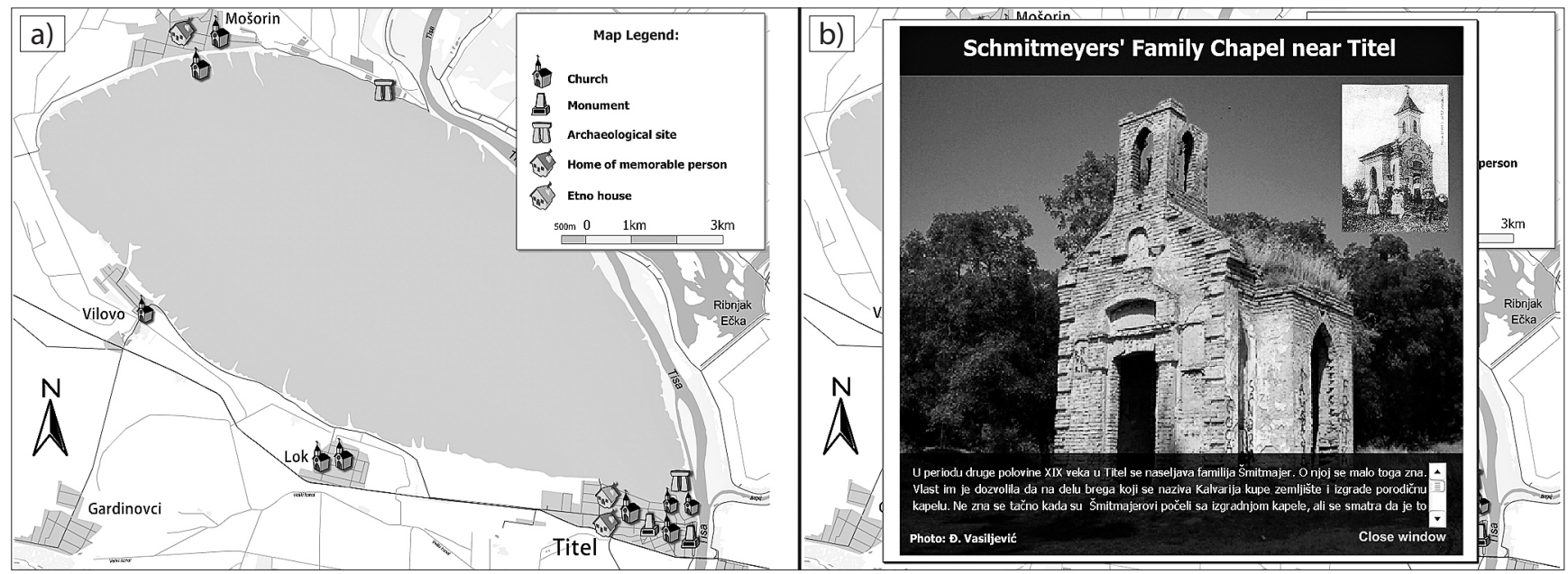

Figure 3 Map of cultural and historical heritage: a) Initial state b) Active state (Vasiljević, 2008)

of soil types that can be turned on in the same time, so users can get a complete pedologic map at once. All displayed layers (read soil types) are marked with "check" sign which appears next to the name of soil type in the map legend.

The second example, which is also a second type of interactivity, is map of cultural and historical heritage (Figure 3a). As its name clearly implies, this map presents attractive cultural and historical sites of the area. Every location is presented by an appropriate symbol (church, monument, statue, etc), which, when clicked by users, displays an image and some (scrollable) textual information about location. The use of scrollable textboxes enables the author to input unlimited amounts of text with more space left on the screen for other applications (such as pictures) (Figure $3 \mathrm{~b}$ ).

In addition to these two maps, the Internet presentation of the (geo) tourism destination could include several interactive maps with different themes and purposes:

- Interactive map of loess disposal in Vojvodina (Figure 1) - this map will provide users with the most important loess regions and profiles in this Serbian Province, with additional textual information and pictures of every important loess profile.

- Interactive map of conservation zones - every visitor to the protected area should be informed about levels of protection and allowed and forbidden operations in these areas. This map would give user detailed instructions and diffusion of these areas.

- Interactive map of attractive loess profiles (Figure 4) and another loess geoheritage gives (potential or present) visitors a visual disposition of all important and attractive geomorphologic phenomena in loess of this destination. When users click on the desired icon on the map, which represents certain profiles, a new window shows visual and textual information of the site.

- Interactive map of accommodation presents spatial distribution of available accommodation in the immediate vicinity, such as hotels, motels, camps, houses, etc. When the users click on the desired symbol on the map that represents certain accommodation, they get all the necessary data required to make a reservation much easier (category, address, telephone, web site, email, outdoor and indoor pictures of the object).

All these maps, together with maps of some other themes, can be applied in numerous modern media (such as mailed out CDs/DVDs) that would serve for the enhanced promotion of the Titel loess plateau as a geotourism destination. They can further be integrated into the official web site of Titel loess plateau (as Geopark), touch-screen panels posted in visitor centres or other points inside destination's area, or
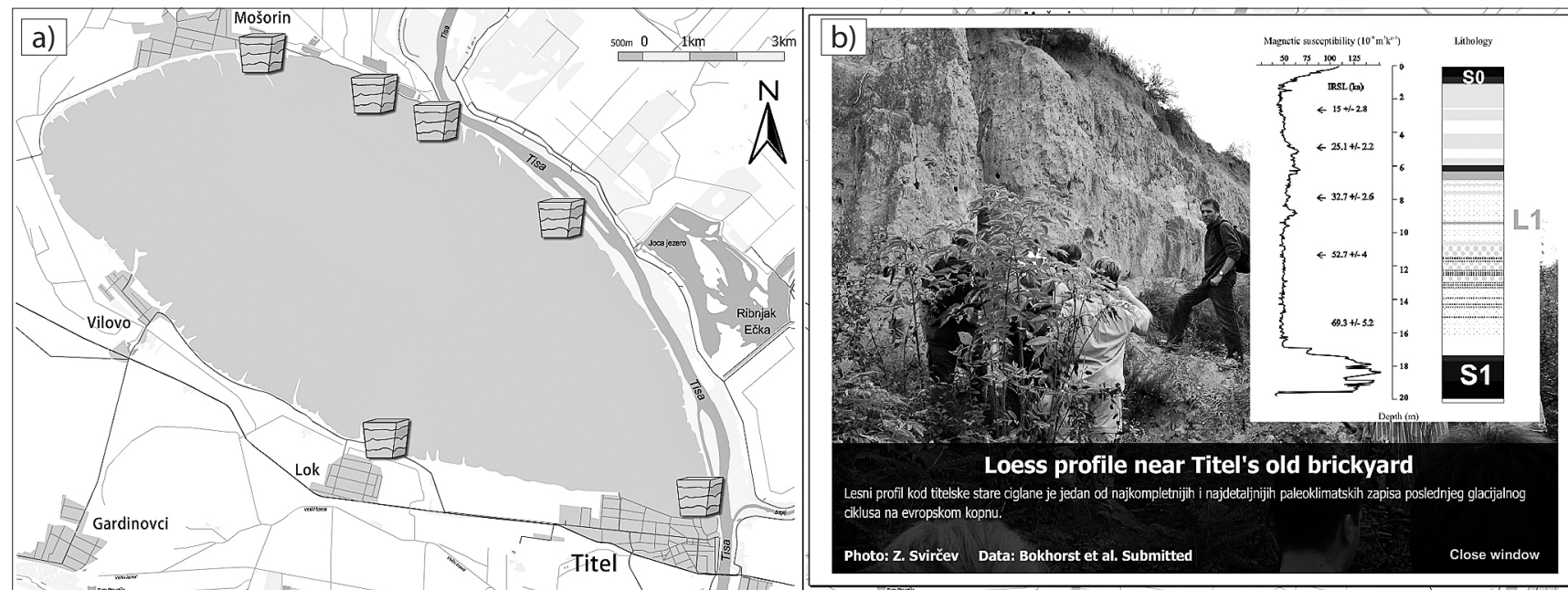

Figure 4 Map of attractive loess profiles: a) Initial state b) Active state (Vasiljević, 2008) 
even burnt on promotional CDs/DVDs that would be sold in souvenir shops or shared with associates and various related organisations (Vasiljević, 2008).

\section{Conclusion}

Tourist maps perform a valuable service and source of information for tourists, making it possible for them to "explore, learn, identify, navigate, orient, and feel somewhat confident in a new or unfamiliar environment" (Richmond, 2002). However, the nature of tourist maps is evolving. The new trend of promotion and education via interactive thematic maps has become common in the tourism business community. The Internet and the dynamic and interactive capabilities of its multimedia interface, have affected the purpose, use, and design of tourism maps. These changes are exciting and offer new opportunities for their design, implementation, and creativity.

Unfortunately, when it is about the use of dynamic maps on websites related to tourist destinations in Serbia, tourism marketing, especially internet tourism marketing has not yet made much of an effort to develop this innovative resource. There are still more scanned, view-only maps, of low quality and resolution in use than is ideal.

This paper has shown that it is possible, with small investments and effort while making these maps, to promote certain destination and provide potential visitors with all the necessary information - a truly cost-effective improvement in communicating with potential income-generating tourists. Geotourism, as a new and still purely developed trend in Serbian tourism needs to use modern technologies to make such destinations not only attractive to scientists and nature-lovers but to all people willing to learn about the world around us.

\section{Acknowledgement}

This work is supported by the Ministry of Science and Technological Development, Republic of Serbia (grant 146019).

\section{References}

Antoine, P., Rousseau, D.D., Fuchs, M., Hatté C., Gautier, C., Marković, S.B., Jovanović, M., Gaudeenyi, T., Moine, O., Rossignol, J. 2009. High resolution record of the last climatic cycle in the Southern Carpathian basin (Surduk, Vojvodina, Serbia). Quaternary International 198, 19-36.

Bokhorst, M.P., Beets, C.J., Marković, S.B., Gerasimenko, N.P., Matviishina, Z.N., Frechen, M. 2009. Pedo-chemical climate proxies in Late Pleistocene Serbian-Ukrainian loess sequences. Quaternary International 198, 123-133.

Barretino, D., Wimbledon, W.A. \& Gallego, E. (eds.) 2000. Geological Heritage: Its Conservation and Management. Sociedad Geologica de Espana/Instituto Technologico GeoMinero de Espana/ ProGEO, Madrid, Spain.

Bronger A. 2003. Correlation of loess-paleosol sequences in East and Central Asia with SE Central Europe - Towards a continental Quaternary pedostratigraphy and paleoclimatic history. Quaternary International 106-107, 11-31. Bronger, A. 1976. Zur Quartären Klimaund Landschaftsentwicklung des Karpatenbeckens auf (paläo-) pedologischer und Bodengeographischer Grundlage, Selbstverlag des geographischen Instituts der Universität Kiel, Kiel, 1-267.

Butrym, J. , H. Maruszcak, and M. Zeremski 1991. Thermoluminescence stratigraphy on Danubian loess in Belgrade environs. Annales UMCS, B 46, 53-64.

Buggle, B., Glaser, B., Hambach, U., Marković, S.B., Gerasimenko, N., Glaser, I., Zöller, L. 2008. Geochemical characterization and provenance of South-East and East European loesses (Serbia, Romania, Ukraine). Quaternary Science Reviews 27, 1058-1075.

Buggle, B., Hambach, U., Glaser, B., Gerasimenko, N., Marković, S., Glaser, I., Zöller, L. 2009. Magnetic susceptibility stratigraphy and spatial and temporal paleoclimatic trends in East European loess paleosol sequences. Quaternary International 196, 86-106.

Fuchs, M., Rousseau D.D., Antoine, P., Hatte, C., Gautier, C., Marković, S.B., Zöller, L. 2008. High resolution chonology of the upper Pleistocene loess/paleosol sequence at Surduk, Vojvodina, Serbia. Boreas 37, 66-73.

Gaudenyi, T., Jovanović, M., Marković S.B., 2007. Reconstruction of the Pleniglacial Environment based of Molluscan assemblages of the Titel Old Brickyard Section (Vojvodina, Serbia). World Congress of Malacology. Antwerp, Belgium 15-20 July 2007. Abstract book: 71.

GEOinformatics, magazine for Geo-IT Professionals, International Institute for Aerospace Survey and Earth Sciences ITC, Enschede, Netherlands, 2000

Hose, T. A., 1995. Selling the Story of Britain's Stone, Environmental Interpretation, 10,2,16-17.

Hose, T.A.,1999. How Was It For You? - Matching Geologic Site Media To Audiences in Oliver,P.G. (ed.) Proceedings of the First UK RIGS Conference. Worcester University College, Worcester, UK. pp.117-144.

Hose T. (2000). European Geotourism - An overview of the promotion of geoconservation through interpretative provision, Symposium "Zukunftsfähiger Geotourismus - Ein Baustein zur lokalen Agenda 21”, Bad Urach, Germany.

Hose, T.A., 2003. Geotourism in England: A Two-Region Case Study Analysis: unpublished PhD thesis, University of Birmingham, Birmingham, UK.

Hose, T.A., 2005a. Geo-Tourism - Appreciating the deep side of landscapes in Novelli, M. (ed.) Niche Tourism; contemporary issues, trends and cases, Elsevier Science, Oxford, UK, pp.27-37.

Hose, T.A., 2005b. Writ in Stone: A Critique of Geoconservation Panels and Leaflets in Wales and the Welsh Borders in Coulson, M.R. (ed.) Proceedings of the Ist Stone in Wales: Materials, Heritage and Conservation conference 2002. National Museum of Wales/CADW, Cardiff, UK, pp.54-6o.

Hose, T.A., 2008. Towards a history of Geotourism: definitions, antecedents and the future in Burek, C.V. \& Prosser, C.D. The History of Geoconservation. Geological Society of London, London, UK, pp.37-6o. 
http://www.nationalgeographic.com/travel/sustainable/ about_geotourism.html (Accessed on 14th January 2009)

Kałamucki,K., Pasoń, M., 2007. Use of tourist maps for study of tourist infrastructure development based on the example of the polish Tatras, Proceedings of the XXIII International Cartographic Conference, Moscow, Russia.

Kariotis, G., Panagiotopoulos, E., Kariotou, G., Karanikolas N., 2007. Creation of a digital interactive tourist map with the contribution of G.P.S. and G.I.S. technology to visualization of the information, Proceedings of the XXIII International Cartographic Conference, Moscow, Russia.

Kraak, M.J. and Brown, A. 2001. Web Cartography: Developments and Prospects, Taylor \& Francis, London, UK.

Marković S. B., Heller, F., Kukla, G., Gaudenyi, T., Jovanović, M. and Miljković, Lj. 2003. Magnetostratigraphy of the Stari Slankamen loess-paleosol sequences (Vojvodina, Serbia and Montenegro). Researches review of the Department of Geography, Tourism and Hotel Management 32, 20-28. (in Serbian with English summary)

Marković S.B., Kostić, N., Oches, E.A. 2004a. Paleosols in the Ruma loess section. Revista Mexicana de Ciencias Geológicas 21, 79-87.

Marković, S.B., Oches, E.A., Gaudenyi, T., Jovanović, M., Hambach, U., Zöller, L., Sümegi P, 2004b. Paleoclimate record in the Late Pleistocene loess-palesol sequence at Miseluk (Vojvodina, Serbia). Quaternaire 15, 361-368.

Marković, S.B., Jovanović, M., Mijović, D., Bokhorst, M., Vandenberghe, J., Oches E, Hambach, U., Zöller, L., Gaudenyi, T., Kovačev , N., Boganović Ž., Savić, S., Bojanić D., Milojković N. 2005a. Titel loess plateau - Geopark. 2nd Conference on the Geoheritage of Serbia, Belgrade 22-23 June 2004, 177-184.

Marković, S.B., McCoy, W.D., Oches, E.A., Savić, S., Gaudenyi, T., Jovanović, M., Stevens, T., Walther, R., Ivanišević, P., Galović Z. 2005b. Paleoclimate record in the Late Pleistocene loess-paleosol sequence at Petrovaradin Brickyard (Vojvodina, Serbia). Geologica Carpathica 56, 545-552.

Marković, S.B., Oches, E., Sümegi, P., Jovanović, M. and Gaudenyi, T. 2006a. An introduction to the Upper and Middle Pleistocene loess-paleosol sequences of Ruma section (Vojvodina, Yugoslavia). Quaternary International 149, 80-86.

Marković, S.B., Hambach, U., Gaudenyi, T., Jovanović, M., Savić, S., Zöller, L., Machalett, B., Savić, S., Romelić, J., Mesaroš, M. 2006b. An introduction to the Late Pleistocene loess-pal eosol sequences of Susek section (Vojvodina, Serbia). Geographica Pannonica 10, 4-8.

Marković, S.B., Oches, E.A., McCoy, W.D., Gaudenyi, T. and Frechen, M. 2007a. Malacological and sedimentological evidence for "warm" climate from the Irig loess sequence (Vojvodina, Serbia). Geophysics, Geochemistry and Geosystems 8, Q09008, doi:10.1029/2006GCo01565.

Marković, S.B., Hambach, U., Oches, E.A., McCoy, W.D., Zoeler, L., Jovanović, M. 2007b. 850 Millennia of paleoclimatic history recorded in the loess sequences of Vojvodina region, Serbia. Quaternary International 167/168 suppl., 269.

Marković, S.B., Bokhorst, M, Vandenberghe, J., Oches, E.A., Zöller, L., McCoy, W.D., Gaudenyi, T., Jovanović, M., Hambach, U., Machalett, B. 2008. Late Pleistocene loesspaleosol sequences in the Vojvodina region, North Serbia. Journal of Quaternary Science 23, 73-84.

Marković, S.B., Hambach, U., Catto, N., Jovanović, M., Buggle, B., Machalett, B., Zöller, L., Glaser, B. Frechen, M. 2009. The middle and late Pleistocene loess-paleosol sequences at Batajanica, Vojvodina, Serbia. Quaternary International 198, 255-256.

Marković, S.B., Hambach, U., Stevens, T., Kukla. G.J., Heller, F., Machalett., B., Oches E.A., Jovanović, M., Gaudenyi, T., Buggle, B., Zöller, L. in preparation. The last million millennia recorded at the Stari Slankamen loesspaleosol sequence: revised chronostratigraphy and longterm environmental trends.

Mathiesen, M., Marketing on the Internet, Gulf Breeze, Florida: Maximum Press, 1995.

Neumann, A. and Winter, A.M. 2001. Time for SVG1- Towards high quality inter-active web maps, Proceedings of the $20^{\text {th }}$ International Cartographic Conference, Bejing, China.

Nivala, A.-M., Brewster, S., Sarjakoski, L.T., 2007. Usability problems of web map sites, Proceedings of the XXIII International Cartographic Conference, Moscow, Russia.

Pecsi, M. 1966. Lösse und Lössartige Sedimente im Karpatenbecken und Ihre lithostratigraphische Gliederung, Teil 2. Petermanns Geographische Mitteilungen 110, 241-252

Richmond, E.R., 2002. Maps and Tourism on the Web: An Online Survey, online version of master thesis, Department of Geography, University of Victoria.

Stojanović, V., Stamenković, I., 2008. Geotourism in context of contemporary touristic movements. Researches review of Serbian Academy of Arts and Sciences, Sheet LXXXVIII, No. 4, 53-58. (in Serbian with English summary)

Vasiljević, Dj., 2008. Tourist and Geographical Information System of Future Loess Geopark in Serbia, unpublished master thesis, Department for Geography, Tourism and Hotel Management, Faculty of Science, Novi Sad. (in Serbian with English summary)

Zeeden C., Hark M., Hambach U., Marković, S.B., Zöller L. 2007. Depressions on the Titel loess Plateau: Form - Pattern - Genesis. Geographica Pannonica 11, 4-8.

Zonn, Leo, 1990. Place Image in Media: Portrayal, Experience, and Media, Maryland: Rowman \& Littlefield Publishers 